\title{
EVALUATION OF THYROID DISORDERS IN SUDANESE PATIENTS WITH DOWN SYNDROME
}

\author{
Ayman FatahAlrahman. A. Babiker 1, Mosab. O. Khalid 1, Haghamad Allzain 2 四 (iD) \\ ${ }^{* 1}$ Department of Clinical Chemistry, Faculty of Medical Laboratory Sciences, Shendi University, \\ Sudan \\ ${ }^{2}$ Department of Biochemistry, Faculty of Medicine, Shendi University, Sudan
}

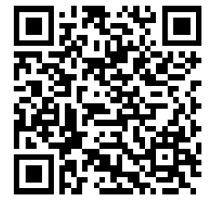

DOI: https://doi.org/10.29121/granthaalayah.v8.i12.2020.2523

Article Type: Research Article

\section{Article Citation: Ayman}

FatahAlrahman. A. Babiker, Mosab.

O. Khalid, and Haghamad Allzain.

(2020). EVALUATION OF THYROID

DISORDERS IN SUDANESE

PATIENTS WITH DOWN

SYNDROME. International Journal of

Research -GRANTHAALAYAH,

8(12), 24-29.

https://doi.org/10.29121/granthaa

layah.v8.i12.2020.2523

Received Date: 25 November 2020

Accepted Date: 24 December 2020

\section{Keywords:}

Down Syndrome

Hypothyroidism

Thyroxine

T3

$\mathrm{T} 4$

TSH

\section{ABSTRACT}

Down syndrome is the most common life compatible chromosomal disorder responsible for the majority of mental retardation and deaths in infancy and childhood. The current study intended to evaluate the thyroid disorders in Sudanese patients with Down syndrome by assessment of thyroid function tests (T3, T4 \& TSH). It was descriptive case control study, carried out in Khartoum, the capital of Sudan, from March to July 2018. It included fifty (50) participants, thirty (30) of them as case group with Down syndrome and twenty (20) normal healthy subjects as control group. Their ages ranged from seven (7) to twenty-eight (28) years.

The study findings showed significant variation in TSH level with mean \pm SD $(2.66 \pm 1.91),(1.67 \pm 0.81)$ in case and control group respectively with P. value (0.001). There was also significant variation when compared children and adults mean TSH level \pm SD $(1.88 \pm 1.11),(2.59 \pm 1.92)$ with P. value of (0.03). There were insignificant differences in T3 level with mean \pm SD (1.04 \pm 0.32$),(1.11 \pm 0.86)$ between case and control group respectively with P. value of (0.08). There was also insignificant difference in T4 level with mean \pm SD $(6.09 \pm 2.06)$, $(6.40 \pm 1.89)$ in case and control group respectively with $\mathrm{P}$. value of (0.7). There were also insignificant differences in T4 and T3 levels between the age groups. As regard to the gender of the patients, there were insignificant differences of TSH, T4, and T3.

\section{INTRODUCTION}

\subsection{BACKGROUND}

Down syndrome (DS), is congenital anomaly caused by supernumerary copies of the whole chromosome twenty-one (21) and refer to as Trisomy or Mongolism. It is the most common, compatible with life chromosomal defect in human. It is also associated with high incidence of other congenital anomalies such as cardiac and gastrointestinal malformations [1].

The clinical features of Down syndrome include flat face with oblique palpebral fissures and epicanthic folds, simian hand crease and severe mental retardation. Forty (40\%) percent have congenital heart disease, especially endocardial cushion, defects, which is responsible for the majority of deaths in infancy and childhood. There is also

(C) 2020 The Author(s). This is an open access article distributed under the terms of the Creative Commons Attribution License, which permits unrestricted use, distribution, and reproduction in any medium, provided the original author and source are credited. 
(10- to 20) fold increased risk of acute leukemia. There are abnormal immune responses leading to recurrent respiratory infections, thyroid autoimmunity and premature Alzheimer disease in late adulthood [2].

\subsection{RATIONALE}

Subjects with Down syndrome are large vulnerable groups in various societies. They have special needs and need special concern. Thyroxines (T4, T3) are important hormones for normal general body function, metabolism and growth. Thyroxines are secreted from thyroid glands under stimulation of thyroid stimulating hormone (TSH). Reported association of thyroid autoimmunity and hypothyroism with Down syndrome further complicated the clinical picture of this congenital anomaly with more cognitive and linear growth retardation. Often hypothyroidism in patients with Down syndrome was missed although some studies reported increased incidence of thyroid disease among such patients. To the best of understanding of the existing knowledge, there is no published data of thyroid disorders among Sudanese patients with Down syndrome. Therefore, the present study would add knowledge and highlight the importance of screening test for thyroid function among this vulnerable group.

\subsection{OBJECTIVES}

The general objective of the current study was to evaluate the thyroid function among the Sudanese Down syndrome patients as regard to the incidence and sex distribution.

\section{MATERIALS AND METHODS}

This was descriptive case control laboratory-based study, carried out in Khartoum from March to July 2018. It included thirty (30) subjects with Down syndrome as case group and twenty (20) normal healthy subjects as control group. Of all the study group, twenty-four (24): forty-eight (48) \% were males and twenty-six (26): fifty-two (52) \% were female.

Structural questionnaire was used for collection of personal information.

Subjects under any treatments that effect of T3, T4, TSH were excluded from the study.

Three (3) ml of venous blood sample is collected aseptically without additives from each participant. Store at (18-25 c) until cloting which occurred usually between (15-45 $\mathrm{min})$, then centerifuge to obtain the serum for assay of T3, T4, TSH.

The volume of serum required for analysis was $(25 \mu \mathrm{l})$ for T3, $(10 \mu \mathrm{l})$ for T4 and (100 $\mu \mathrm{l})$ for TSH.

Estimation of TSH was performed based on immune-enzymatic assay was performed entirely in the ST AIAPACK TSH test cups by sing full automated TOSOH AIA 360. T3 and T4 was performed based on competitive enzyme immunoassay by full automated TOSOH AIA 360.

The results of TSH were displayed as $(\mu \mathrm{IU} / \mathrm{ml})$ with reference interval $(0.4$------ $3.6 \mu \mathrm{IU} / \mathrm{ml})$ for normality. The results of T4 were displayed as $(\mu \mathrm{g} / \mathrm{dl})$ with reference interval : $4.9----11 \mu \mathrm{g} / \mathrm{dl}$ ( for the normality. The results for T3 were displayed as (ng/ml) with reference interval: $(0.79$------ $1.58 \mathrm{ng} / \mathrm{ml})$ for the normality.

\section{DATA ANALYSIS}

All collected data was analyzed using SPSS for windows, version 16, Pearson Chi-Square test was used for categorical data with $p$ value $\leq 0.05$ as significant. Analysis of variance (ANOVA) was used for continuous data and the statistical results were presented as means \pm SD.

\subsection{ETHICAL CLEARANCE}

Ethical approval for the study was obtained from the Board of the Faculty of Graduates Studies and Scientific Research in Shendi University. Written informed consent for was obtained from each guardian of participant as well as from the subject himself before recruitment into the study, according to the international protocols for human research. 


\section{RESULTS}

Table 1: Mean and St.d of $\mathrm{T}_{4}, \mathrm{~T}_{3}$ and TSH in case group (Down syndrome patients ) and control normal group (Healthy subjects).

\begin{tabular}{|c|c|c|c|}
\hline Parameter & Case group & Control group & $P$. value \\
\hline $\mathrm{T}_{4}(\mu \mathrm{g} / \mathrm{dl})$ & $6.09 \pm 2.06$ & $6.40 \pm 1.89$ & 0.70 \\
\hline $\mathrm{T}_{3}(\mathrm{ng} / \mathrm{ml})$ & $1.04 \pm 0.32$ & $1.11 \pm 0.86$ & 0.08 \\
\hline $\mathrm{TSH}(\mu \mathrm{lU} / \mathrm{ml})$ & $2.66 \pm 1.91$ & $1.67 \pm 0.81$ & 0.001 \\
\hline
\end{tabular}

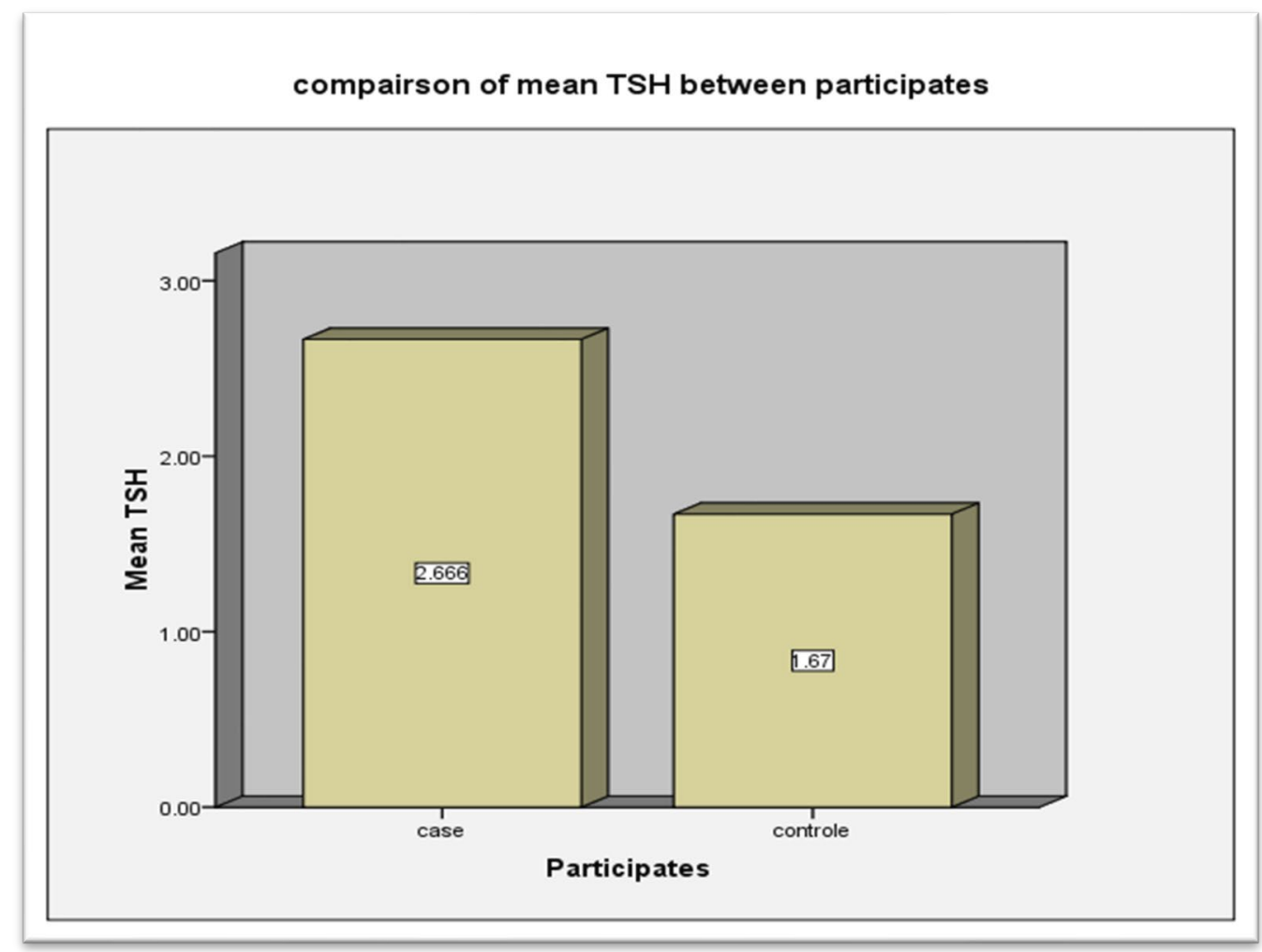

Figure 1: Comparison mean of TSH in case group (Down syndrome patients) and control normal group (Healthy subjects).

Table 2: Comparison of mean and St.d of $\mathrm{T}_{4}, \mathrm{~T}_{3}$ and $\mathrm{TSH}$ between the age group(children and adult ) of Down syndrome patients.

\begin{tabular}{|c|l|l|l|}
\hline Parameter & $\begin{array}{l}\text { Children } \\
\text { (7-17 years) }\end{array}$ & $\begin{array}{l}\text { Adult } \\
\text { (18-28 years) }\end{array}$ & $P$.value \\
\hline $\mathrm{T}_{4}(\mu \mathrm{g} / \mathrm{dl})$ & $2.25 \quad 6.49 \pm$ & $1.73 \quad 5.98 \pm$ & 0.3 \\
\hline $\mathrm{T}_{3}(\mathrm{ng} / \mathrm{ml})$ & $1.11 \pm 0.28$ & $1.04 \pm 0.26$ & 0.8 \\
\hline $\mathrm{TSH}(\mu \mathrm{lU} / \mathrm{ml})$ & $1.88 \pm 1.11$ & $2.59 \pm 1.92$ & 0.03 \\
\hline
\end{tabular}




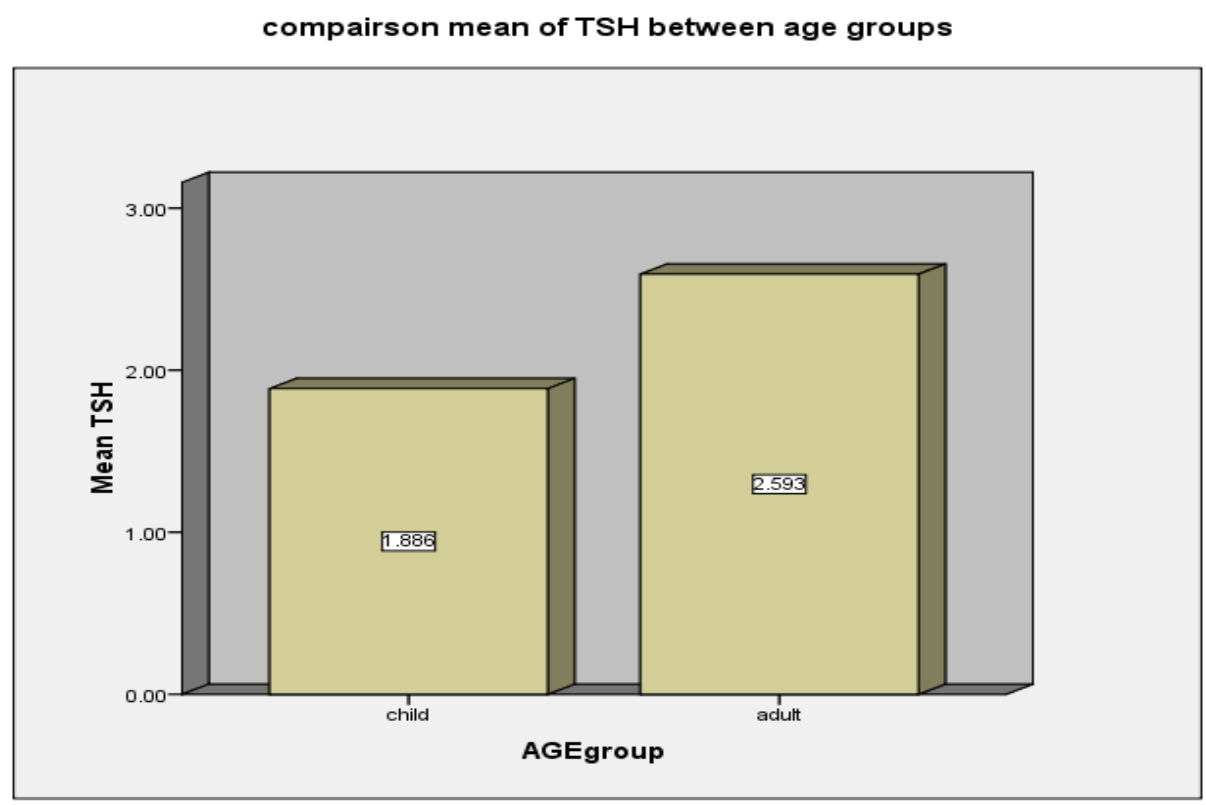

Figure 2: comparison mean of TSH between age groups case group (Down syndrome patients) and control normal group (Healthy subjects).

Table 3: Comparison of mean and St.d of $\mathrm{T}_{4}, \mathrm{~T}_{3}$ and TSH between the sex group of Down syndrome patients.

\begin{tabular}{|l|l|l|l|}
\hline Parameter & Male & Female & $P$.value \\
\hline $\mathrm{T}_{4}(\mu \mathrm{g} / \mathrm{dl})$ & $6.40 \pm 1.87$ & $6.05 \pm 2.10$ & 0.8 \\
\hline $\mathrm{T}_{3}(\mathrm{ng} / \mathrm{ml})$ & $1.12 \pm 0.28$ & $1.02 \pm 0.25$ & 0.7 \\
\hline $\mathrm{TSH}(\mu \mathrm{lU} / \mathrm{ml})$ & $2.24 \pm 1.23$ & $2.28 \pm 1.95$ & 0.1 \\
\hline
\end{tabular}

\section{DISCUSSION}

The findings of the present study showed significant differences in TSH level between case and control group with mean $(2.66,1.67 \mu \mathrm{IU} / \mathrm{ml})$ in case and control group respectively with $P$. value of $(0.001)$ as appeared in table (1). This finding agreed with the result of Cutler AT, et al., who demonstrated that the Down syndrome cohort had mildly increased (TSH) [3]. It also agreed with result of Prasher V\& Gomez G. who showed that Down syndrome patients appear to have high-normal plasma TSH levels [4]. Also, Moosa S, et al observed wide spectrum of thyroid dysfunction was represented in their cohort study [5]. The current findings disagreed with those presented by Prasher $\mathrm{V}$, et al who figured out gradual decline in thyroid-stimulating hormone with age. Their study was designed to investigate further the natural history of thyroid dysfunctions in adults with Down syndrome over a 15-years period and further recommend frequent evaluation of thyroid function in adults with Down Syndrome (6).

There were significant differences in TSH level between age group which is higher in adults than children with mean $(2.59,1.88 \mu \mathrm{IU} / \mathrm{ml})$ respectively with $P$. value of $(0.03)$, as in table (2). This finding suggested gradual decline of thyroid function with age. It contradicted the findings of Prasher V, et al. who found gradual decline in thyroidstimulating hormone with age [6].

In table (1); there was insignificant difference in $\mathrm{T}_{3}$ level with mean $(1.04,1.11 \mathrm{ng} / \mathrm{ml})$ in case and control groups respectively with $P$. value of $(0.08)$. There was also insignificant difference in $\mathrm{T}_{4}$ level with mean $(6.09,6.40)$ in case and control groups respectively with $P$. value of (0.7). These findings coincided partially with those obtained by Cutler AT, et al, who found that twenty-seven (27\%) percent of the Down syndrome cohort had normal thyroxine levels (3). The findings of Prasher V, \& Gomez G. demonstrated that sixty-three (63\%) percent of Down syndrome subjects were euthyroid with normal $\mathrm{T}_{4}$ [4]. Other finding of King K, et al. presented that sixty (60\%) percent of children with Down syndrome had subclinical hypothyroidism and normal $\mathrm{T}_{4}$ [7], [8]. Also, Moosa $\mathrm{S}$, et al illustrated 
that around twenty-eight (28.7\%) percent of Down syndrome had subclinical hypothyroidism and normalT 4 . [5]. The current result contradicted the findings demonstrated by Prasher V, et al. that there was gradual increase in thyroxine level [6].

There were insignificant differences of thyroid function as evaluated by $\left(\mathrm{T}_{3}, \mathrm{~T}_{4}\right.$ \&TSH) between males and females with Down Syndrome and it was agreed with findings outlined by Cutler AT, et al, who found insignificant differences as regard to Down syndrome patients' sex [3]. The findings of this current study agreed with the results obtained by Melinda J. Pierce, et al, who concluded that thyroid disease in Down Syndrome is more common and occurs earlier than in the general population, and is often transient. Thyroid disease is unrelated to the patient's gender [9].

\section{CONCLUSION}

The study concluded that the Down syndrom patients have higher levele of TSH than nomal individuals and this indicated greater thyroid stimulstion by TSH, with tendency of clinical and subclinical hypothyroidism. Furthermore, TSH level were higher in adults than childern among Down syndrome subjects, indicated further increasing deterioration of thyroid function with older age.

\section{RECOMMENDATIONS}

Based on the findings of this study it is highly recommended that;

The thyroid function should be evaluated for every patient with Down syndrome and followed up by scheduled screening thyroid function test for earlier detection and treatment of any deterioration in thyroid function, so as to prevent further deteriorations of already compromised cognitive function and linear growth [10].

\section{SOURCES OF FUNDING}

This research received no specific grant from any funding agency in the public, commercial, or not-for-profit sectors.

\section{CONFLICT OF INTEREST}

The author has declared that no competing interests exist.

\section{ACKNOWLEDGMENT}

None.

\section{REFERENCES}

[1] Antonarakis SE, Lyle R, Dermitzakis ET, Reymond A, Deutsch S. Chromosome 21 and down syndrome: from genomics to pathophysiology. Nature reviews genetics. 2004;5(10): 725.

[2] Pentao L, Wise CA, Chinault AC, Patel PI, Lupski JR. Charcot-Marie-Tooth type 1A duplication appears to arise from recombination at repeat sequences flanking the $1.5 \mathrm{Mb}$ monomer unit. Nature genetics. 1992;2(4):292.

[3] Cutler AT, Benezra-Obeiter R, Brink SJ. Thyroid function in young children with Down syndrome. American Journal of Diseases of Children. 1986;140(5):479-83.

[4] Prasher V, Gomez G. Natural history of thyroid function in adults with Down syndrome-10-year follow-up study. Journal of Intellectual Disability Research. 2007;51(4):312-7.

[5] Moosa S, Segal DG, Christianson AL, Gregersen NE. Thyroid dysfunction in a cohort of South African children with Down syndrome. SAMJ: South African Medical Journal. 2013;103(12):966-70.

[6] Prasher V, Ninan S, Haque S. Fifteen-year follow-up of thyroid status in adults with Down syndrome. Journal of Intellectual Disability Research. 2011;55(4):392-6. 
[7] King K, O'Gorman C, Gallagher S. Thyroid dysfunction in children with Down syndrome: a literature review. Irish journal of medical science. 2014;183(1):1-6.

[8] King K, O'Gorman C, Gallagher S. An audit of the management of thyroid disease in children with Down syndrome. Irish medical journal. 2014.

[9] Melinda J. Pierce, Stephen H. LaFranchi, Joseph D. Pinter. Characterization of Thyroid Abnormalities in a Large Cohort of Children with Down Syndrome. Horm Res Paediatr .2017;87: 170-178.

[10] Nitash Zwaveling-Soonawala, M Emma Witteveen, Jan Pieter Marchal, Femke C C Klouwer, Nadine A Ikelaar, Anne M J B Smets, Rick R van Rijn, Erik Endert, Eric Fliers and A S Paul van Trotsenburg. Early thyroxine treatment in Down syndrome and thyroid function later in life. European Journal of Endocrinology. May 2017; Volume 176: Issue 5. Pages: 505-513. 